\title{
UPAYA MENINGKATKAN AKTIVITAS DAN HASIL BELAJAR SISWA TENTANG MENULIS PERMULAAN DENGAN MENGGUNAKAN MEDIA KARTU KATA PADA SISWA KELAS SDN BAJO
}

\author{
${ }^{1}$ Hadijah M. Saleh, Suhardi Abdullah ${ }^{2}$ \\ hadijasaleh@gmail.com; suhardiabd@gmail.com \\ 1,2 Program Studi Pendidikan Guru Sekolah Dasar (PGSD) Universitas Khairun
}

\begin{abstract}
The research objectives consist of (1) Increasing prewriting activity through words card at $3^{\text {rd }}$ grade of SDNegeri Bajo and (2) Increasing students prewriting activities through word cards. There were 22 students became the respondents of this reearch and this research used quantitative and qualitative approach with classroom action research (CAR). The result of this research showed that there was significant difference between $1^{\text {st }}$ cycle and $2^{\text {nd }}$ cycle showed up that there were positive and negatively reacting respond by the students. In using word cards media showed that students were more enjoyable in learning process. Based on the research result of learning foundout that 7,1\% average. It is proved that card words media could improved students competence in learning prewriting in cycle one with categorize suficiently. While in the second cycle became 19 students passed attend their evaluation or 19 students of 20 students, thus the percentage reach $95 \%$. Based on the second cycle of the research, the researcher assumed that the students prewriting competence through word cards increase at $3^{\text {rd }}$ grade of SDNegeri Bajo
\end{abstract}

Keywords: Prewriting, Action Research, Learning Result and Word

\section{PENDAHULUAN}

Kemampuan berbahasa sangat dibutuhkan bagi semua individu. Hal ini disebabkan keterampilan berbahasa merupakan model untuk mengembangkan kemampuan intelektual, sosial, dan karakter siswa. Di sekolah pembelajaran bahasa Indonesia diarahkan untuk meningkatkan empat keterampilan berbahasa, yakni menyimak, berbicara, membaca, dan menulis. Oleh sebab itu, pembelajaran berbahasa di sekolah diharapkan dapat membantu peserta didik mengembangkan potensi-potensi diri lainnya. Pentingnya penguasaan keterampilan berbahasa, khususnya menulis.

Mata pelajaran Bahasa Indonesia merupakan mata pelajaran penting yang berperan mengembangkan banyak segi kehidupan siswa. Dikatakan demikian karena melalui bahasa siswa dapat memperoleh pengetahuan, teknologi, dan seni secara baik. Pentingnya penguasaan keterampilan berbahasa, khususnya pada menulis Tarigan (2008:4) menjelaskan bahwa kemampuan menulis merupakan ciri orang atau bangsa yang terpelajar. Kemajuan suatu bangsa dapat dilihat dari maju tidaknya komunikasi tulis bangsa tersebut. Namun demikian, tujuan tersebut dapat tercapai dengan baik apabila seseorang dapat menuangkan ide dan gagasan secara baik dan sistematis ke dalam satu tulisan yang dapat dipahami secara jelas. Untuk mencapai itu, tentu melalui proses pembelajaran yang telah ditanam secara baik semenjak awal, dalam hal ini pada siswa yang masih menduduki bangku Sekolah Dasar (SD).

Keterampilan berbahasa (menulis) yang harus diajarkan oleh guru dan harus dikuasai siswa Sekolah Dasar (SD) dengan baik, sehingga tidak melahirkan stigma-stigma buruk terhadap keterampilan berbahasa tersebut. Bisa jadi siswa tidak dapat menulis dengan baik atau tidak menyukai kegiatan menulis disebabkan pembelajaran menulis di Sekolah Dasar (SD) yang tidak menyenangkan bagi mereka. Hal ini sesuai dengan pandang Suparno dan Yunus (2003:1.4), bahwa seseorang yang tidak suka menulis karena tidak tahu apa yang harus ditulis, meresa tidak berbakat menulis, dan merasa tidak tahu bagaimana dia harus menulis. Ketidaksenangan tersebut muncul sebagai akibat dari pengaruh lingkungan keluarga dan masyarakatnya, serta pengalaman 
pembelajaran siswa yang tidak menyenangkan, kurang termotivasi, dan tidak merangsang sewaktu di sekolah.

Dalman (2014:5), menjelaskan bahwa menulis dalam prosesnya akan menggunakan kedua belahan otak. Menulis adalah sebuah proses mengait-ngaitkan antara kata, kalimat, paragraf, maupun antar bab secara logis agar dapat dipahami. Sesuai pendapat ini, maka disimpulkan bahwa menulis sebagai suatu proses melibatkan banyak kesiapan, terutama kesiapan menyangkut hal teknik maupun non teknik. Menulis tidak semudah membalik telapak tangan, tetapi melalui suatu proses.

Pada akhirnya, aktivitas dan proses menulis di sekolah khususnya Sekolah Dasar (SD) melibatkan guru dan siswa secara aktif. Guru adalah sosok yang memegang kendali jalannya proses pembelajaran, termasuk di dalamnya adalah mendesain model pembelajaran yang tepat, guna meningkatkan keterampilan menulis siswa. Salah satu tindakan inovasi guru dalam meningkatkan proses dan hasil menulis permulaan pada siswa Sekolah Dasar (SD) adalah memilih dan menetapkan media yang tepat serta meberikan rangsangan positif bagi siswa dalam kegiatan menulis. Hal ini sesuai dengan penjelasan Zulela (2012:73), guru merupakan faktor penentu dalam mencapai keberhasilan pembelajaran.

Pembelajaran Bahasa Indonesia di Sekolah Dasar (SD) diarahkan untuk meningkatkan kemampuan siswa dalam berkomunikasi secara baik dan benar. Komunikasi ini mencakup lisan maupun tulisan. Dengan demikian, siswa kelak akan memiliki perkembangan karakter yang baik terkait rasa menghargai karya orang lain. Apabila ditelaah kurikulum, khususnya KTSP, ruang lingkup kajian mata pelajaran bahasa Indonesia di Sekolah Dasar secara umum dikembangkan dalam empat aspek keterampilan yaitu:

\section{Keterampilan Menyimak}

Keterampilan menyimak adalah suatu proses keterampilan yang kompleks. Keterampilan ini meliputi mendengarkan, memahami, menafsirkan bunyi-bunyi yang telah dikenalnya, kemudian mencoba memaknai bunyi-bunyi tersebut, dan meresponnya (Santosa, 2005: 6.24). Tujuan mendasar pembelajaran menyimak pada siswa SD, yakni melatih pemahaman bahasa lisan dan melatih keterampilan logika berpikirnya, sehingga siswa dapat merespon, menerima, memahami, mengidentifikasi, menafsirkan, dan mereaksi informasi yang diterimanya dari individu yang lain. Kompetensi umum pembelajaran menyimak adalah mendengarkan suara, berita, petunjuk, pengumuman, bunyi bahasa, kaset lagu, penjelasan, laporan, ceramah/khotbah, pidato, pembicaraan narasumber, seminar, dan pengumuman agar siswa dapat merespon dan mengapresiasi yang didengarkannya.

\section{Keterampilan Berbicara}

Menurut Tarigan (dalam Saddhono, 2012: 34), berbicara adalah bagian dari komunikasi lisan, yaitu penyampaian pesan melalui bahasa lisan oleh pembicara. Berbicara berarti mengemukakan keinginan, perasaan, ide atau pesan lisan secara baik. Berbicara merupakan keterampilan berbahasa yang produktif sebab keterampilan ini berfungsi sebagai sarana transformasi informasi yang mengandung pengetahuan. Mengingat pentingnya kedudukan keterampilan berbicara dalam kehidupan setiap individu, maka menjadi kewajiban bahwa individu tersebut harus terampil berkomunikasi untuk menyampaikan pikiran, gagasan, ide, dan perasaannya baik secara lisan maupun tulis. Kompetensi umum keterampilan berbicara, yakni mengungkapkan gagasan dan isi hati; menyampaikan sambutan, ceramah/khotbah, dialog, pengalaman, pesan, proses; menceritakan diri sendiri, teman, keluarga, kegiatan sehari-hari masyarakat, tanaman, benda, pengalaman, binatang, gambar seri, gambar tunggal, kejadian, kesukaan/ketidaksukaan, tokoh, tata tertib, peraturan dan sebagainya. 


\section{Keterampilan Membaca}

Saddhono (2012:64) menjelaskan bahwa membaca bukan hanya sekedar menyuarakan lambang-lambang bahasa yang tertulis saja, melainkan harus memahami rangkaian kata/kalimat yang ucapkan. Dalam kegiatan membaca, pembaca harus tahu persis sistem lambang tulisan yang digunakannya. Misalnya, kosakata. Selanjutnya pembaca menentukan kata kunci untuk mengidentifikasi gagasan dan topik bacaan yang ia baca, sehingga ia dapat mengetahui dan memahami isi bacaan secara tepat. Pemahaman terhadap bacaan adalah suatu proses yang bergulir dan berkesinambungan. Oleh sebab itu, dalam pembelajaran membaca, proses input informasi dan pengetahuan ke dalam otak siswa harus tterbentuk, caranya memberikan peluang kepada siswa untuk memperoleh penjelasan tmengenai bagian-bagian teks bacaan yang belum dipahaminya.

\section{Keterampilan Menulis}

Keterampilan berbahasa terakhir, yakni menulis. Keterampilan ini merupakan keterampilan yang bersifat produktif dibandingkan dengan yang lainnya sebab bersifat menghasilkan suatu produk atau karya baru. Di antara ketiga keterampilan bahasa yang lain, menulis merupakan keterampilan yang paling kompleks karena menulis bukan sekedar menyalin kata atau kalimat melainkan lebih pada menuangkan ide dan pikiran dalam bentuk tulisan yang sistematis, sehingga pembaca dapat memahaminya dengan mudah. Menulis merupakan proses penuangan ide atau gagasan dalam bentuk teks karangan/tulisan, berupa rangkaian simbol-simbol bahasa.

Dalam proses pembelajaran bahasa Indonesia di Sekolah Dasar, keempat aspek keterampilan bahasa ini harus diajarkan dan dikembangkan secara maksimal. Keempat aspek ini harus diajarkan secara seimbang, terpadu, dan terarah supaya tujuan pembelajaran bahasa Indonesia di Sekolah Dasar benar-benar dapat tercapai. Tidak hanya sekedar melaksanakan tugas mengajar, yang pada akhirnya menimbulkan berbagai stigma negatif terhadap pembelajaran bahasa Indonesia bagi siswa.

Berdasarkan Standar Isi yang terdapat pada KTSP (BSNP, 2006:119), tujuan pembelajaran Bahasa Indonesia di sekolah adalah: (1) berkomunikasi secara efektif dan efisien sesuai dengan etika yang berlaku, baik secara lisan maupun tulis; (2) menghargai dan bangga menggunakan bahasa Indonesia sebagai bahasa persatuan dan bahasa Negara; (3) memahami bahasa Indonesia dan menggunakannya dengan tepat dan kreatif untuk berbagai tujuan; (4) menggunakan bahasa Indonesia untuk meningkatkan kemampuan intelektual, serta kematangan emosional dan sosial; (5) menikmati dan memanfaatkan karya sastra untuk memperluas wawasan, memperhalus budi pekerti, serta meningkat-kan pengetahuan dan kemampuan berbahasa; (6) menghargai dan membanggakan sastra Indonesia sebagai khazanah budaya dan intelektual manusia Indonesia.

\section{A. Hakikat Menulis}

\section{Pengertian Menulis}

Tarigan (2008:22) menyatakan bahwa kegiatan menulis, yakni menurunkan atau melukiskan lambang-lambang grafik yang menggambarkan suatu bahasa yang dapat dipahami oleh seseorang, sehingga orang lain dapat membaca lambang-lambang grafik tersebut kalau memahami bahasa dan gambaran grafik mengemukakan pendapat dengan strategi yang diperhitungkan. Namun tanpa kehilangan rasa dan spontanitas.

a. Draft kasar; tahap ini awali dengan mengembangkan ide-ide. Pusatkan pada isi dari pada tanda baca, tata bahasa, maupun ejaan.

b. Berbagi; sebagai penulis sulit bagi kita untuk menulis secara objektif. Oleh sebab itu, perlu meminta pendapat dan masukan pihak lain untuk membaca dan memberikan umpan balik. Mintalah kesediaan sejawat untuk membaca tulisan dan mengatakan bagian mana yang benar- 
benar kuat dan menunjukkan ketidakkonsistenan, kalimat yang tidak jelas, tidak logis, atau transisi yang lemah, dan ketidakefektifan topik permasalahan.

c. Perbaikan (revisi); apabila telah mendapat umpan balik dari sejawat mengenai mana yang baik dan mana yang perlu digarap lagi, ulangi dan perbaikilah.

d. Menyunting (editing); pada tahap ini, perbaikilah semua kesalahan ejaan, tata bahasa, dan tanda baca. Pastikanlah semua transisi berjalan mulus, peng-gunaan kata kerja tepat, dan kalimat-kalimat lengkap.

e. Penulisan kembali; tulis kembali tulisan, masukkan isi yang baru dan perubahan-perubahan penyuntingan.

f. Evaluasi (menilai): periksalah lagi kembali untuk memastikan bahwa Anda telah menyelesaikan apa yang Anda rencanakan dan apa yang ingin Anda sampaikan dalam tulisan secara efektif dan mudah.

\section{Dasar-Dasar Pembelajaran Menulis}

Semenjak siswa berada di sekolah dasar kelas 1, pembelajaran menulis telah diajarkan kepada mereka. Artinya bahwa keterampilan menulis tidak didapatkan secara ilmiah. Namun, pengenalan menulis pada anak bukan harus semenjak masuk sekolah. Menurut Strickland dalam Burns, et al (1996: 42), anak mulai membaca dan menulis dalam awal hidupnya tanpa pengajaran formal. Bahkan sebelum anak menguasai kegiatan menulis, anak sudah dapat memahami sebuah cerita dan dapat ia perdenarkan kepada orang lain. Pernyataan tersebut tentunya agak benarnya, sebab anak sebelum dapat membaca dan menulis, mereka sudah dapat memahami cerita dan dapat ia ceritakan kepada orang lain.

Kaitannya dengan itu, Jalango (1992:233) mengemukakan bahwa "menggambar dan menulis merupakan proses mengarang yang digunakan anak untuk berkomunikasi". Dengan demikian, agar kemampuan menulis dapat dikembangkan, salah satunya dengan cara mengajari anak belajar menulis melalui tulisan. Faris (1993: 182) menjelaskan bahwa "apabila menginginkan anak memiliki keterampilan menulis, hendaknya dalam belajar menulis mereka harus aktif berpartisipasi dalam mengerjakan tugas-tugas menulis". Pendapat diterima dengan syarat bahwa untuk mengembangkan keterampilan menulis pada anak, maka ia harus sering latihkan belajar menulis. Oleh sebab itu, berbagai metode pembelajaran yang melibatkan partisipasi aktif siswa dapat menjadi alternatif yang dipilih oleh guru dalam pembelajarannya.

\section{Menulis Permulaan}

Menulis permulaan merupakan langkah awal yang ditempuh siswa sekolah dasar dalam pembelajaran menulis. Untuk itu, dalam proses pembelajaran menulis permulaan perlu dilakukan beberapa tahap atau fase. Slamet (2008:73) mengemukakan sebelum pembelajaran menulis permulaan diajarkan kepada anak, guru hendaknya memperhatikan langkah persiapan pramenulis permulaan. Kegiatan paramenulis persiapan tersebut, meliputi: (1) siswa harus duduk dengan wajar dan baik (kepala tegak, punggung lurus, posisi tangan dan kaki pada tempatnya); (2) meletakkan buku tangan dengan jarak ke mata yang cukup dengan sudut tegak lurus; (3) memegang buku dengan baik, membuka buku dari kanan ke kiri, mulai halaman 1, 2, dan seterusnya, melihat tulisan dimulai dari kiri menuju ke kanan, dari atas menuju ke bawah; (4) melemaskan lengan tangan dengan gerakan menulis ke udara; (5) memegang pensil dengan benar (pensil tajam, jarak mata, pensil dari jari cukup posisi atau kemiringan pensil benar, dan posisi tangan kiri benar; (6) melemaskan jari dengan mewarnai, menjiplak, menggambar, meniru, melatih dasar menulis (garis tegak, garis miring, garis lurus, dan garis lengkung); (7) melemaskan jari dengan cara menuliskan huruf dengan menggunakan jari (di bak pasir, di tanah, di meja, atau di udara).

Djago, Tarigan (5.44-5.49) mengemukakan, bahwa langkah-langkah menulis permulaan terbagi ke dalam dua kelompok, yakni: (a) pengenalan huruf dan (b) latihan. Pada pengenalan 
huruf, pembelajaran ditekankan dan diarahkan pada pengenalan bentuk tulisan serta pelafalannya bunyi dengan benar. Langkah-langkah yang hendak dilakukan guru dalam memperkenalkan huruf, contoh mengenalkan huruf a, i, dan o, adalah sebagai berikut: (1) guru menunjukkan gambar seorang anak kecil dan seorang anak remaja. Kedua anak tersebut diberi nama yang berbeda, "Dino" dan "Dina", (2) gru memperkenalkan kedua anak itu sambil menunjukkan tulisan keduanyan yang tertera di bawah masing-masing gambar, (3) melalui proses tanya-jawab secara berulang, anak diminta menunjukkan mana "Dino" dan mana "Dina, sambil diminta menunjuk bentuk tulisannya, (4) selanjutnya guru memindahkan dan menuliskan kedua bentuk tulisan tersebut di papan tulis dan anak diminta menyimak dan memerhatikannya. Guru dianjurkan menulis secara perlahan-lahan, supaya anak dapat memerhatikan gerakan-gerakan tangan serta contoh pengucapan dari bentuk tulisan yang ditulis guru, (5) tulisan yang ditulis selanjutnya dianalisis dan dihubungkan kembali.

\section{METODE PENELITIAN}

Penelitian ini menggunakan pendekatan kualitatif dan kuantitatif, dengan jenis Penelitian Tindakan Kelas (PTK). Pendekatan kualitatif untuk memperoleh data proses pembelajaran, sedangkan pendekatan kuantitatif untuk menghitung dan menganalisis data produk/hasil. Sementara rangkaian kegiatan dalam PTK ini mengacu pada model yang dikemukakan oleh Arikunto (2009:3) mengartikan PTK sebagai suatu pencermatan terhadap kegiatan belajar berupa sebuah tindakan, yang sengaja dimunculkan dan terjadi dalam sebuah kelas secara bersama. Pelaksanaan PTK ini melalui empat tahap, yaitu perencanaan, pelaksanaan, pengamatan, dan refleksi.

Tujuan utama melakukan PTK, yaitu untuk meningkatkan dan memperbaiki praktek yang seharusnya dilakukan oleh guru, sehingga guru akan lebih banyak berlatih mengapliklasikan berbagai tindakan alternatif sebagai upaya untuk meningkatkan aktivitas dan proses pembelajaran dari pada perolehan pengetahuan dalam bidang pendidikan yang dapat digeneralisasikan.

\section{PEMBAHASAN}

Awal mula diketahui bahwa kemampuan menulis permulaan siswa kelas III SD Negeri Bajo tergolongg rendah. Hal ini diketahui setelah melakukan tes awal peneliti kepada siswa. Tes awal diikuti sejumlah siswa kelas III SD Negeri Bajo. Peneliti memberikan tes, dari hasil tes peneliti analisis dan diketahui persentase klasikal, yakni 46\%. Hal ini membuktikan bahwa sebagian besar siswa belum memiliki kemampuan menulis dengan baik secara individual. Berdasarkan refleksi awal oleh peneliti berkesimpulan memperbaiki kemampuan menulis pada kalangan siswa kelas III SD Negeri Bajo. Media kartu kata dianggap sebagai cara efektif guna mengantisipasi kemampuan siswa tersebut.

Pelaksanaan pembelajaran pada siklus I, diterapkannya media kartu kata, ternyata cukup efektif. Hasil yang dicapai pada siklus I memang masih tergolong rendah, belum mencapai kriteria keberhasilan. Melalui tahapan dan perencanaan pembelajaran yang baik, maka proses dan hasil pembelajaran secara perlahan dapat diatasi. Kegiatan-kegiatan sesuai tahapan, seperti menyanyi bersama, mengarahkan siswa menulis abdjad, mengarahkan siswa menulis huruf menjadi kata dan kalimat. Proses bimbingan secara intens dari peneliti kepada siswa menjadi indikator penting keberhasilan. Tindakan penguatan dan evaluasi dilakukan untuk mengukur tingkat kemampuan siswa.

Perolehan hasil, baik proses maupun hasil pada siklus I, jumlah skor 22 dengan peresentase rata-rata $68,75 \%$. Hasil pengamatan yang dilakukan sejawat terhadap proses pembelajaran siswa 
meliputi: a) Kesiapan siswa mengikuti kegiatan belajar mengajar, perolehan nilai 2; b) Menyimak penjelasan guru, mendapat skor 2; c) Bernyanyi bersama, mendapat skor 3; dan d) Mengeja/menyebutkan huruf abdjad, mendapat skor 2. Aspek-aspek penailaian ini diperoleh siswa secara berbeda antara satu dengan yang lain.

Hasil pelaksanaan pembelajaran siklus I, diketahui bahwa aktivitas siswa dalam proses pembelajaran dengan kemampuan siswa menulis permulaan melalui media kartu kata. Secara umum hasil penelitian siklus I belum mencapai indikator keberhasilan. Hal ini disebabkan siswa belum terbiasa menulis dengan media kartu kata, sehingga mereka membutuhkan penyesuaian. Banyak siswa masih kesulitan menulis, selain daya serap yang masih rendah. Beberapa kekeurangan diidentifikasi, misalnya penyampaian materi yang monoton, tujuan pembelajaran belum dijelaskan secara detail, dan sistematisasi penyampaian materi merupakan hal-hal yang menjadi kendala dalam ketercapaian tujuan pembelajaran. Untuk itu, peneliti bersama sejawat melakukan diskusi untuk menentukan masalah yang akan dipecahkan di samping membuat skenario kelas yang kondusif.

Kegiatan memotivasi siswa, serta mengaitkan materi pembelajaran dengan pengetahuan awal siswa, guru bersama siswa menyanyikan lagu, guru mengarahkan siswa menuliskan huruf abdjad, guru menanyakan kembali kesulitan siswa tentang huruf, kata dan kalimat kepada siswa lalu mereka menuliskannya, guru memberikan membimbing siswa menulis kembali tentang kalimat yang ada bagi siswa yang mengalami kesulitan, guru memberi penguatan sebagai evaluasi akhir pembelajaran dengan skala penilaian yang diperoleh 4 (sangat baik). Mengarahkan siswa mengambil kartu kata secara acak yang telah disediakan dan menuliskan huruf tersebut memperoleh penilaian 3 (baik). Skor total pada siklus II adalah 25. Apabila dirata-ratakan menjadi $8,9 \%$ dan dipresentasekan menjadi $89 \%$. Dengan demikian, aktivitas mengajar guru telah mencapai kategori sangat baik pada siklus II.

Berdasarkan penjelasan di atas dapat diketahui bahwa proses pembelajaran melalui media kartu kata cukup efektif untuk memaksimalkan hasil belajar siswa untuk menulis permulaan. Media kartu kata juga sangat memotivasi siswa untuk aktif membangun skemata pengetahuannya secara individual.

\section{SIMPULAN}

Setelah dianalisis proses dan hasil pembelajaran menulis permulaan menggunakan media kartu kata, baik siklus I maupun II disimpulkan beberapa hal berikut.

1. Proses pembelajaran menulis permulaan dengan media kartu kata pada siswa kelas III SD Negeri Bajo memberikan kemudahan bagi siswa. Hal disebabkan peningkatan aktivitas berupa sikap positif yang diketahui melalui observasi, baik siklus I maupun siklus II. Awalanya ditemukan beberapa masalah dalam proses pembelajaran, seperti kurangnya antusias dan pasif. Namun, masalah tersebut dapat diatasi dengan tindakan memberikan perhatian dan memotivasi siswa yang kesulitan dan tidak konsentrasi. Bimbingan dan upaya menyederhanakan penyampaian materi serta tindakan latihan secara bergantian kepada siswa merupakan faktor keberhasilan penerapan media kartu kata untuk menulis permulaan siswa.

2. Siklus I, diperoleh data untuk skor perolehan dengan mengajar guru adalah 22 , rata-rata nilai 6,8 dipresentasekan 68\%, kategori cukup baik. Skor total siswa adalah 15, dirata-ratakan 7,1, presentasekan mencapai 71\%. Banyaknya siswa yang tuntas berjumlah 11 dari 20 siswa. Presentase ketuntasan klasikal, yakni 55\%. Siklus II skor guru menjadi 31, dirata-ratakan 9,6 dipresentasekan 96\%, kategori sangat baik. Skor total siswa 25, dirata-ratakan 8,9\% 
dipresentasekan 89\%. Siswa tuntas sebanyak 19 orang dari 20 siswa. Presentase klasikal adalah $95 \%$.

\section{DAFTAR PUSTAKA}

Arikunto, Suharsimi. 2010. Prosedur Penelitian. Jakarta: Rineka Cipta.

Arief S. Sadiman dkk. 1996. Media Pendidikan. Jakarta: CV Rajawali.

Aqib, Zainal. 2013. Model-model Media dan Strategi Pembelajaran Kontekstual. Yrama Widya: Bandung.

BSNP. 2006. Panduan Penyusunan Kurikulum Tingkat Satuan Pendidikan Jenjang Pendidikan Dasar dan Menengah. Jakarta: Depdiknas.

Djago Tarigan, dkk. 2006. Pendidikan Bahasa dan Sastra Indonesia di Kelas Rendah. Jakarta: Universitas Terbuka.

Dalman, H. 2014. Keterampilan Menulis. PT Raja Grafindo: Jakarta.

Depdiknas. 2003. Kurikulum 2004 Standar Kompetensi Bahasa Indonesia Sekolah Dasar dan Madarasah Ibtidaiyah. Jakarta: Depdiknas.

Komalawati, Desi. 2012. Yuk, Menulis Esai. Tangerang: TPC Publisher.

Moleong. 2000. Metodologi Penelitian Kualitatif. Bandung: Remaja Rosda Karya.

Resmini, Novi, dkk. 2009. Kebahasaan (Ponologi, Morfologi, Semantik). Bandung: UPI Press.

Santosa, P. et al. 2005. Materi dan Pembelajaran Bahasa Indonesia SD. Jakarta: Universitas Terbuka.

Saddhono, Kundharu dan St, Y, Slamet. 2012. Meningkatkan Keterampilan Berbahasa Indonesia (Teori dan Aplikasi). Bandung: Karya Putra Darwati.

Sanaky, Hujair AH. 2011. Media Pembelajaran. Yogyakarta: Kaukaba Dipantara. 